\title{
Screening of Lactobacillus strains for their ability to produce conjugated linoleic acid in milk and to adhere to the intestinal tract
}

\author{
J. Sosa-Castañeda, ${ }^{*}$ A. Hernández-Mendoza, ${ }^{*}$ H. Astiazarán-García,† H. S. Garcia,‡ M. C. Estrada-Montoya, \\ A. F. González-Córdova, ${ }^{*}$ and B. Vallejo-Cordoba*1 \\ *Laboratorio de Química y Biotecnología de Productos Lácteos, Coordinación de Tecnología de Alimentos de Origen Animal, \\ Centro de Investigación en Alimentación y Desarrollo A.C. (CIAD), Carretera a La Victoria Km. 0.6 Hermosillo, Sonora 83304, Mexico \\ †Laboratorio de Patología Experimental, Coordinación de Nutrición, Centro de Investigación en Alimentación y Desarrollo, A.C. (CIAD), \\ Hermosillo, Sonora 83304, Mexico \\ łUnidad de Investigación y Desarrollo en Alimentos (UNIDA) Instituto Tecnológico de Veracruz M. A. de Quevedo, Veracruz, Veracruz 91897 , \\ Mexico
}

\section{ABSTRACT}

Conjugated linoleic acid (CLA) has been shown to provide beneficial effects on health; however, the amount consumed in food is far from that required for the desired effects. Thus, increasing the CLA content in dairy foods through milk fermentation with specific lactic acid bacteria (LAB) offers an interesting alternative. Moreover, some LAB may be able to adhere to the intestinal mucosa and produce CLA through endogenous synthesis. Therefore, the objective of this study was to screen LAB isolates for their ability to produce CLA in skim milk and in simulated gastrointestinal conditions. Additionally, the ability of selected CLA-producing $\mathrm{LAB}$ to adhere to the intestinal mucosa in a murine model was assessed. Results showed that of 13 strains of Lactobacillus tested, only 4 were able to produce CLA in skim milk supplemented with linoleic acid (13.44 \pm 0.78 to $50.9 \pm 0.26 \mu \mathrm{g} / \mathrm{mL}$ ). Furthermore, these 4 Lactobacillus strains were able to survive and produce CLA in simulated gastrointestinal conditions and to adhere to the intestinal mucosa of Wistar rats after $7 \mathrm{~d}$ of oral inoculation with fluorescently labeled bacteria. Accordingly, these 4 Lactobacillus strains may be used to manufacture fermented dairy foods to increase CLA content, and consumption of these fermented milks may result in CLA produced endogenously by these LAB.

Key words: lactic acid bacteria, Lactobacillus, conjugated linoleic acid, fermented milk

\section{INTRODUCTION}

Conjugated linoleic acid is a mixture of positional and geometric isomers of linoleic acid (LA; cis-9, cis-12 $\mathrm{C} 18: 2)$, with the isomers cis-9,trans-11 $(\boldsymbol{c} \mathbf{9}, \mathbf{t 1 1})$ and

Received June 24, 2014.

Accepted June 3, 2015.

${ }^{1}$ Corresponding author: vallejo@ciad.mx trans-10,cis-12 $(\boldsymbol{t 1 0 , c 1 2})$ being the only isomers that have been shown to have potential anticarcinogenic, antiinflammatory, antiobesogenic, and anticholesterolemic effects (O'Shea et al., 2004; Bhattacharya et al., 2006; Park, 2009). It has been reported that milk and dairy products are the foods with the highest CLA content (Chin et al., 1992; Lin et al., 1995; Fritsche and Steinhart, 1998; Gagliostro, 2005; Prandini et al., 2007; Herman-Lara et al., 2012). However, CLA concentration in milk is dependent on feed (Chouinard et al., 2001; Gagliostro, 2005), oil supplementation (Flowers et al., 2008; Benchaar et al., 2012), and breed (Hernández-Mendoza et al., 2009) of the cow. To date, the exact amount of CLA required to obtain beneficial effects in humans is not known. However, it has been estimated that $3.5 \mathrm{~g} / \mathrm{d}$ could protect against cancer (Ip et al., 1994), and $3.2 \mathrm{~g} / \mathrm{d}$ was shown to produce a moderate loss of body fat in humans (Whigham et al., 2007). Based on these previous studies, the estimated amount of CLA consumption in a typical diet (36 to $440 \mathrm{mg} / \mathrm{d}$ ) is below the amount required for the desired effects (Fritsche and Steinhart, 1998; Nunes and Torres, 2010). Thus, it may be of interest to look for strategies to increase CLA content in food.

Studies have shown that CLA may be synthesized by specific lactic acid bacteria (LAB) in de Man, Rogosa, and Sharpe (MRS) broth (Hernandez-Mendoza et al., 2009; Liu et al., 2011) and Bifidobacterium or LAB in milk (Rodríguez-Alcalá et al., 2011; Pandit et al., 2012) or yogurt (Florence et al., 2009; do Espirito Santo et al., 2012). Other studies showed that some LAB may produce CLA in cream (Domagała et al., 2009) or cheese (Van Nieuwenhove et al., 2007b; Lima Alves et al., 2011). Thus, one of the most effective methods to increase CLA uptake in humans is to increase CLA levels in dairy products by using strains with high CLA production potential (Lee et al., 2007). In addition, it has been shown that specific LAB may be able to produce CLA after adhering to the intestinal epithelial 
cells in animal models (Lee et al., 2006; Wall et al., 2009) or in humans (Lee and Lee, 2009) after administration as a freeze-dried product in saline buffer. Thus, CLA production by bacteria adhered to the intestinal wall may enhance CLA content in addition to that provided by the CLA-producing strains in fermented milk, to yield the desired effects to the host.

Because CLA production is strain dependent (Kim and Liu, 2002), the search for new LAB capable of producing CLA in milk and in the intestinal tract may be of interest for the manufacture of fermented dairy foods. Previous studies have screened LAB and Bifidobacterium for their CLA-producing ability in fermented dairy products (Xu et al., 2004; Abd El-Salam et al., 2010; Pandit et al., 2012). Screening of LAB for the production of CLA under simulated gastrointestinal conditions may be useful before in vivo assessment. However, studies exploring the potential of CLA production by LAB under simulated gastrointestinal conditions are scarce (Roman-Nunez et al., 2007). The production of CLA in the intestine by LAB is of interest because typical intakes of LA are estimated to be 12 and 17 $\mathrm{g} / \mathrm{d}$ for woman and men, respectively, suggesting that enough substrate is available for microbial production of CLA (Rett and Whelan, 2011). Thus, the objectives of this research were to search for LAB strains capable of producing CLA in milk and under simulated gastrointestinal conditions. Additionally, we assessed the in vivo adherence ability of selected CLA-producing bacteria to determine the potential of these bacteria for production of CLA under physiological conditions.

\section{MATERIALS AND METHODS}

\section{Materials and Chemicals}

Nonfat dry milk (USDA organic grade A) was from Organic Valley (La Farge, WI); MRS broth was obtained from BD-Difco Laboratories (Sparks, MD); linoleic acid, phosphatidylcholine, methanolic hydrochloric acid, chloroform, methanol, anhydrous sodium sulfate, $\mathrm{NaCl}, \mathrm{KCl}, \mathrm{CaCl}_{2}, \mathrm{NaHCO}_{3}$, lysozyme, pepsin, bile salts (Ox-bile), and pancreatin were obtained from Sigma Chemicals Co. (St. Louis, MO). Methyl 9(Z),11(E)-octadecadienoate and methyl 10(E),12(Z)octadecadienoate analytical standards were from Matreya LLC (Pleasant Gap, PA).

\section{Lactic Acid Bacteria}

All 13 wild Lactobacillus strains were obtained from the culture collection of the Dairy Laboratory at the Food Research and Development Center, A.C. (CIAD, A.C., Hermosillo, Sonora, Mexico). These strains were isolated during the making of artisanal cheese in Hermosillo. Lactobacillus reuteri ATCC 55739 was included as a CLA-producing strain (Roman-Nunez et al., 2007). Before each experiment, Lactobacillus strains were subcultured in MRS broth at $37^{\circ} \mathrm{C}(\mathrm{pH}$ 6.5). Three consecutive cultures ( $1 \%$ inoculum) were prepared and incubated for 24, 20, and $18 \mathrm{~h}$, respectively. The last culture was used as the inoculum for all experiments (fresh culture).

\section{Preparation of Gastrointestinal Fluids}

Saliva, gastric, and intestinal solutions were prepared according to the protocol described by Fernández de Palencia et al. (2008). Simulated saliva was prepared with $6.2 \mathrm{~g} / \mathrm{L} \mathrm{NaCl}, 2.2 \mathrm{~g} / \mathrm{L} \mathrm{KCl}, 0.22 \mathrm{~g} / \mathrm{L} \mathrm{CaCl}_{2}, 1.2$ $\mathrm{g} / \mathrm{L} \mathrm{NaHCO}_{3}$ and $0.01 \%$ lysozyme. Simulated gastric juice was prepared with $6.2 \mathrm{~g} / \mathrm{L} \mathrm{NaCl}, 2.2 \mathrm{~g} / \mathrm{L} \mathrm{KCl}$, $0.22 \mathrm{~g} / \mathrm{L} \mathrm{CaCl} \mathrm{Ca}_{2}, 1.2 \mathrm{~g} / \mathrm{L} \mathrm{NaHCO}_{3}$ and $0.3 \%$ pepsin. Simulated intestinal juice was prepared with $5 \mathrm{~g} / \mathrm{L}$ $\mathrm{NaCl}, 0.6 \mathrm{~g} / \mathrm{L} \mathrm{KCl}, 0.3 \mathrm{~g} / \mathrm{L} \mathrm{CaCl}_{2}, 0.45 \%$ bile salts, and $0.1 \%$ pancreatin.

\section{Screening of CLA-Producing Strains in MRS Broth or Skim Milk}

Stock solution of LA micelles was prepared by preparing a $7.5 \%$ solution of phosphatidylcholine in LA as reported by Hernandez-Mendoza et al. (2009). Subsequently, the LA micellar stock solution was added into MRS broth (LA-MRS) or reconstituted NDM (LA-RNDM; 10\%) to obtain a final concentration of $2 \%$. The LA-MRS and LA-RNDM were sterilized at $121^{\circ} \mathrm{C}$ for $15 \mathrm{~min}$ and $110^{\circ} \mathrm{C}$ for $10 \mathrm{~min}$, respectively. Finally, LA-MRS or LA-RNDM was inoculated with fresh culture $(1 \%)$ and incubated at $37^{\circ} \mathrm{C}$ for $48 \mathrm{~h}$ in a water bath shaker (Lab-Line Instruments Inc., Melrose Park, IL) set at $200 \mathrm{rpm}$ under aerobic conditions. After this incubation period, samples were analyzed for CLA content by gas chromatography. Each LAB strain was analyzed in triplicate.

\section{CLA Production in Simulated Gastrointestinal Conditions}

To simulate gastrointestinal conditions, the methodology reported by Kabak and Ozbey (2012) was used with some modifications. First, MRS broth $(45 \mathrm{~mL})$ were inoculated with $1 \%$ fresh culture and incubated for $18 \mathrm{~h}$ at $37^{\circ} \mathrm{C}$. The cell pellet was harvested after centrifugation at $4,696 \times g$, washed twice with PBS, and suspended in $4.5 \mathrm{~mL}$ of PBS. Subsequently, $6 \mathrm{~mL}$ of simulated saliva solution was added, the $\mathrm{pH}$ was adjusted to $\mathrm{pH} 6.5$ with $1 \mathrm{M} \mathrm{HCl}$, and the solution was 
incubated for $5 \mathrm{~min}$ at $37^{\circ} \mathrm{C}$ with shaking (200 rpm). After this time, $12 \mathrm{~mL}$ of simulated gastric juice was added, the $\mathrm{pH}$ was adjusted to 3 with $1 \mathrm{M} \mathrm{HCl}$, and the solution was incubated for $2 \mathrm{~h}$ at $37^{\circ} \mathrm{C}$ with shaking. Finally, $18 \mathrm{~mL}$ of simulated intestinal juice solution containing $0.2 \%$ of LA micellar solution was added, the $\mathrm{pH}$ was adjusted to $\mathrm{pH} 6.5$ with $1 \mathrm{M} \mathrm{NaHCO}_{3}$, and the solution was incubated for $24 \mathrm{~h}$ at $37^{\circ} \mathrm{C}$ with shaking. Each LAB strain was analyzed in triplicate.

\section{CLA Determination by GC}

The lipid fraction was extracted from $2 \mathrm{~mL}$ of MRS broth, skim milk, or gastrointestinal fluid using $20 \mathrm{~mL}$ of a 2:1 mixture of chloroform and methanol (Folch et al., 1957). Subsequently, the lipids were reconstituted in $200 \mu \mathrm{L}$ of chloroform, and $1 \mathrm{~mL}$ of $1 N$ methanolic hydrochloric acid was added. The mixture was allowed to react for $30 \mathrm{~min}$ at $60^{\circ} \mathrm{C}$. The methylation reaction was stopped by addition of $200 \mu \mathrm{L}$ of distilled water. The FAME were extracted twice in hexane $(1 \mathrm{~mL})$ and the extract was desiccated by addition of anhydrous sodium sulfate (Hernandez-Mendoza et al., 2009). Then, FAME $(1 \mu \mathrm{L})$ were injected into a Hewlett Packard 6890 GC system (Hewlett Packard, Wilmington, DE) equipped a SP-2560 capillary column $(100 \mathrm{~m} \times 0.25$ $\mathrm{mm}, 0.2 \mu \mathrm{m}$ thickness; Supelco, Bellefonte, PA) and a flame-ionization detector (Agilent Technologies, Wilmington, DE). The injector and detector temperatures were 240 and $260^{\circ} \mathrm{C}$, respectively. Helium was used as the carrier gas with a constant flow of $1.5 \mathrm{~mL} / \mathrm{min}$ with a split ratio of 1:5. The temperature program was as follows: $140^{\circ} \mathrm{C}$ for $4 \mathrm{~min}$, to $176^{\circ} \mathrm{C}$ at $9^{\circ} \mathrm{C} / \mathrm{min}$, and to $180^{\circ} \mathrm{C}$ at $2^{\circ} \mathrm{C} / \mathrm{min}$. The total run time was 70 min. Methyl 9(Z),11(E)-octadecadienoate and methyl 10(E),12(Z)-octadecadienoate were used as analytical standards for the identification and determination of CLA. For CLA quantitation, a 5-point standard curve was constructed.

\section{Bacterial Survival Under Simulated Gastric and Intestinal Conditions}

Fresh culture $(10 \mathrm{~mL})$ was centrifuged at $4,696 \times g$ for 15 min at $4^{\circ} \mathrm{C}$ and washed twice with $\mathrm{PBS}$ at $\mathrm{pH}$ 7.2. The cell pellet was suspended in $10 \mathrm{~mL}$ of gastric solution and incubated at $37^{\circ} \mathrm{C}$ for $3 \mathrm{~h}$. Viable counts were made on MRS agar plates before $(0 \mathrm{~h})$ and after 3 $\mathrm{h}$ of exposure to simulated gastric solution. In addition, $100 \mathrm{~mL}$ of the simulated intestinal solution was inoculated with $1 \%$ fresh culture and incubated at $37^{\circ} \mathrm{C}$. Viable counts were carried out by pour-plating with MRS at specified intervals after inoculation and expressed as colony forming units per milliliter. Incubation with each LAB strain was analyzed in duplicate.

\section{Evaluation of Adhesion Capacity of Lactobacillus to Intestinal Epithelial Cells of Rats}

The labeling of the bacteria was carried out following the methodology reported by Duangjitcharoen et al., (2009). The LAB strains (J20, J23, J25, and J26) were grown in MRS broth and incubated for $18 \mathrm{~h}$ at $37^{\circ} \mathrm{C}$. Then, the cell pellet was harvested after centrifugation at $4,696 \times g$ for $15 \mathrm{~min}$ at $4^{\circ} \mathrm{C}$ and washed twice with PBS. Cells were adjusted to $10^{9} \mathrm{cfu} / \mathrm{mL}$ with PBS and labeled with the fluorescent dye carboxyfluorescein diacetate succinimidyl ester (CFDA-SE; $50 \mu M$ ) at $37^{\circ} \mathrm{C}$ for $20 \mathrm{~min}$. During the labeling procedure, strains were incubated for 5 min between washes to allow free unreacted CFDA-SE to be dispersed out of the cells and removed. This reduced the possibility that unbound CFDA-SE in cells would diffuse out to the environment once administered. Finally, LAB were washed with PBS 3 times to remove excess dye. The labeled LAB were observed by using a fluorescence microscope Axio Scope A1 Carl Zeiss (Göttingen, Germany) equipped with a $450-490 \mathrm{~nm}$ filter and a $100 \times / 1.25$ oil immersion objective (A-Plan, Carl Zeiss). Images were analyzed using Zen 2012 lite software (Carl Zeiss).

Four groups of 7 -wk-old Wistar male rats $(\mathrm{n}=3$; Harlan Teklad Inc., Distrito Federal, Mexico) were inoculated daily with the different labeled LAB cultures (1 $\mathrm{mL}$ of $10^{9}$ labeled $\mathrm{cfu} / \mathrm{mL}$ ) for $7 \mathrm{~d}$ using an intragastric tube. A fifth group $(\mathrm{n}=3)$, which served as a control, was administered an unlabeled culture of strain J20. After this period, the rats were killed and the small intestine was removed and washed with sterile distilled water and sterile PBS to remove any residual blood and organic matter. Afterward, the intestine was dissected into 3 parts (duodenum, jejunum, and ileum). Finally, the 3 sections of the small intestine were stained with hematoxylin-eosin and observed by using a fluorescence microscope (Axio Scope A1; Lee et al., 2004).

\section{Statistical Analysis}

A completely randomized design with 3 replicates per treatment was used for quantification of CLA in MRS broth and skim milk, and under simulated gastrointestinal conditions, whereas for viable counts, 2 replicates per treatment were used. Data were analyzed by oneway ANOVA, and then differences among means were analyzed by the Tukey-Kramer test. Statistical analysis was performed using the NCSS statistical software version 2007 (www.ncss.com), and the significance level was set at $P<0.05$. 


\section{RESULTS}

\section{Screening of CLA-Producing Strains in MRS Broth or Skim Milk}

None of the 13 Lactobacillus strains was able to produce CLA in LA-MRS broth (data not shown). However, 4 of the 13 strains were able to produce CLA in LA-RNDM (Table 1). The concentration of CLA produced by these 4 strains of Lactobacillus ranged from $13.44 \pm 0.78$ to $50.9 \pm 0.26 \mu \mathrm{g} / \mathrm{mL}$. The total amount of CLA as well as the proportion of CLA isomers produced was strain dependent. Lactobacillus fermentum J20 produced $80.6 \% c 9, t 11$ and $19.4 \% t 10, c 12$ isomers; $L b$. fermentum J23 produced $31.29 \% c 9, t 11$ and $68.71 \%$ t10,c12 isomers; Lactobacillus plantarum J25 produced $71.5 \% c 9, t 11$ and $28.5 \% t 10, c 12$ isomers; Lactobacillus pentosus J26 produced $100 \%$ c $9, t 11$ isomer, and Lactobacillus reuteri ATCC 55739 produced $54.37 \%$ c9,t11 and $46.22 \%$ t10,c12 isomers.

\section{Bacterial Survival Under Simulated Gastric and Intestinal Conditions}

Counts $(\mathrm{cfu} / \mathrm{mL})$ for $L b$. fermentum $\mathrm{J} 23$ and $L b$. plantarum J25 before and after exposure to simulated gastric conditions were not significantly different $(P>$ $0.05)$, although cell counts decreased by 0.5 and 0.72 logarithmic cycles, respectively. On the other hand, $L b$. fermentum J20 and Lb. pentosus J26 significantly $(P$ $<0.05$ ) decreased their cell counts by 1.11 and 1.14 logarithmic cycles. Figure 1 shows the counts of the 4 Lactobacillus strains when exposed to simulated intestinal conditions for $24 \mathrm{~h}$. The results showed that the 4 Lactobacillus remained viable for $24 \mathrm{~h}$ in simulated intestinal conditions, although $L b$. fermentum J23 and Lb. plantarum J25 cell counts decreased by 0.49 and 0.74 logarithmic log cycles, in relation to cell counts in MRS broth, respectively. Similarly, Lb. fermentum J20 and $L b$. pentosus J26 cell counts decreased by 0.75 and 0.73 logarithmic cycles, respectively. However, differences between survival in simulated intestinal juice and growth in MRS broth at $24 \mathrm{~h}$ were not significantly different $(P>0.05)$ for the 4 strains.

\section{Production of CLA Under Simulated Gastrointestinal Conditions}

Lactobacillus fermentum strains J20 and J23 produced $4.33 \pm 0.42 \mu \mathrm{g} / \mathrm{mL}$ and $2.55 \pm 0.35 \mu \mathrm{g} / \mathrm{mL}$ of CLA, respectively, with no significant difference between them $(P>0.05)$, after being subjected to simulated gastrointestinal conditions (Table 2). On the other hand, Lb. plantarum J25 and Lb. pentosus J26 produced $15.05 \pm 0.76 \mu \mathrm{g} / \mathrm{mL}$ and $36.96 \pm 3.24 \mu \mathrm{g} / \mathrm{mL}$ of CLA, respectively, and were significantly different from $L b$. fermentum J20 and J23 strains $(P<0.05$; Table 2).

\section{Evaluation of Adhesion Capacity of Lactobacillus to Intestinal Epithelial Cells of Rats}

Figure 2, panels A, C, and E show typical histological sections of duodenum, jejunum, and ileum of rats treated with labeled bacteria, and Figure 2, panels B, $\mathrm{D}$, and $\mathrm{F}$ show the fluorescence emitted by labeled bacteria in these same segments of the small intestine. The presence of fluorescence in the tissue was associated with LAB adhesion to the intestine wall. Similar findings were observed for histological sections in the different treatment groups. Thus, the results showed that J20, J23, J25, and J26 strains were able to adhere to the rat intestinal mucosa.

\section{DISCUSSION}

It has been proposed that certain PUFA, including LA, have an inhibitory effect on bacterial growth (Correia et al., 2012). The exact mechanism is not yet well understood; however, the toxicity of LA could be explained by the presence of double bonds, which alter the shape of the molecule. Incorporation of these kinked unsaturated fatty acids in the cell membrane can disrupt the lipid bilayer structure. Another pos-

Table 1. Conjugated linoleic acid-producing Lactobacillus strains in reconstituted NDM containing linoleic acid

\begin{tabular}{|c|c|c|c|c|}
\hline \multirow[b]{2}{*}{ Species } & \multirow[b]{2}{*}{ Strain } & \multicolumn{3}{|c|}{$\mathrm{CLA}(\mu \mathrm{g} / \mathrm{mL} ; \pm \mathrm{SD})$} \\
\hline & & cis-9,trans-11 & trans-10, cis-12 & CLA \\
\hline Lb. fermentum & $\mathrm{J} 20$ & $42.63 \pm 0.91^{\mathrm{a}}$ & $8.27 \pm 0.64^{\mathrm{a}}$ & $50.9 \pm 0.26^{\mathrm{a}}$ \\
\hline Lb. fermentum & $\mathrm{J} 23$ & $7.73 \pm 0.52^{\mathrm{b}}$ & $11.25 \pm 0.51^{\mathrm{b}}$ & $18.98 \pm 1.03^{\mathrm{b}}$ \\
\hline Lb. plantarum & $\mathrm{J} 25$ & $13.72 \pm 0.91^{\mathrm{b}}$ & $9.81 \pm 1.02^{\mathrm{ab}}$ & $23.53 \pm 1.94^{\mathrm{b}}$ \\
\hline Lb. pentosus & $\mathrm{J} 26$ & $13.44 \pm 0.78^{\mathrm{c}}$ & $0^{c}$ & $13.44 \pm 0.78^{\mathrm{c}}$ \\
\hline Lb. reuteri & ATCC 55739 & $45.70 \pm 1.35^{\mathrm{a}}$ & $38.36 \pm 1.54^{\mathrm{c}}$ & $84.07 \pm 0.188^{\mathrm{d}}$ \\
\hline
\end{tabular}

${ }^{\mathrm{a}-\mathrm{d}}$ Values within a column with different superscripts are significantly different $(P<0.05)$. 
Table 2. Conjugated linoleic acid-producing Lactobacillus strains in simulated gastrointestinal conditions

\begin{tabular}{llccr}
\hline & & \multicolumn{3}{c}{ CLA $(\mu \mathrm{g} / \mathrm{mL} ; \pm \mathrm{SD})$} \\
\cline { 3 - 5 } Species & Strain & cis-9,trans-11 & trans-10, $^{\text {cis-12 }}$ & \multicolumn{1}{c}{ CLA } \\
\hline Lb. fermentum & J20 & $1.67 \pm 0.21^{\mathrm{a}}$ & $2.66 \pm 0.21^{\mathrm{a}}$ & $4.33 \pm 0.42^{\mathrm{a}}$ \\
Lb. fermentum & $\mathrm{J} 23$ & $1.43 \pm 0.14^{\mathrm{a}}$ & $1.12 \pm 0.21^{\mathrm{b}}$ & $2.55 \pm 0.35^{\mathrm{a}}$ \\
Lb. plantarum & $\mathrm{J} 25$ & $7.34 \pm 0.44^{\mathrm{b}}$ & $7.71 \pm 0.32^{\mathrm{c}}$ & $15.05 \pm 0.76^{\mathrm{c}}$ \\
Lb. pentosus & $\mathrm{J} 26$ & $36.96 \pm 3.24^{\mathrm{c}}$ & 0 & $36.96 \pm 3.24^{\mathrm{d}}$ \\
Lb. reuteri & ATCC 55739 & $39.10 \pm 1.41^{\mathrm{c}}$ & $24.82 \pm 0.85^{\mathrm{d}}$ & $60.93 \pm 2.27^{\mathrm{e}}$ \\
\hline
\end{tabular}

${ }^{\mathrm{a} e}$ Values within a column with different superscripts are significantly different $(P<0.05)$.

sibility is that diffusion of fatty acids across the membrane causes chemiosmotic difficulties, disturbs the membrane potential, or disconnects intramembrane pathways (Gorissen et al., 2015). Hence, the conversion of LA to CLA isomers by LAB strains could be a detoxification mechanism. The ability of this bioconversion depends on activity of linoleate isomerase. This enzyme has been detected in several bacterial species, including Lactobacillus, and has a strain-dependent activity; thereby, CLA production depends on bacterial strain (Gorissen et al., 2011). In the current study, we found that 4 Lactobacillus strains were able to synthesize CLA in LA-RNDM. Additionally, all strains produced a biologically active isomer. Other studies reported that LAB isolates from different sources were able to produce CLA in skim milk containing LA and the amount produced varied from $2.73 \pm 0.07$ to 131.63 $\pm 5.82 \mu \mathrm{g} / \mathrm{mL}$ (Alonso et al., 2003; Puniya et al., 2009). The results of this study indicated strain $L b$. fermentum J20 produced the most CLA $(50.9 \pm 0.26 \mu \mathrm{g} / \mathrm{mL})$ after $48 \mathrm{~h}$ of fermentation in dairy-based medium. In fact, the production of $c 9, t 11$ by J20 was not signifi-

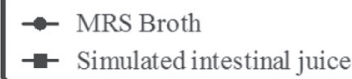

A)

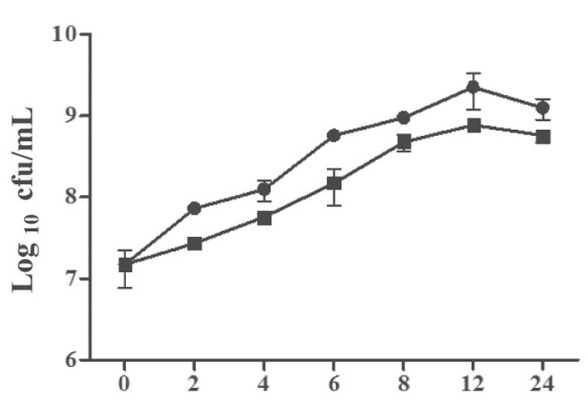

C)

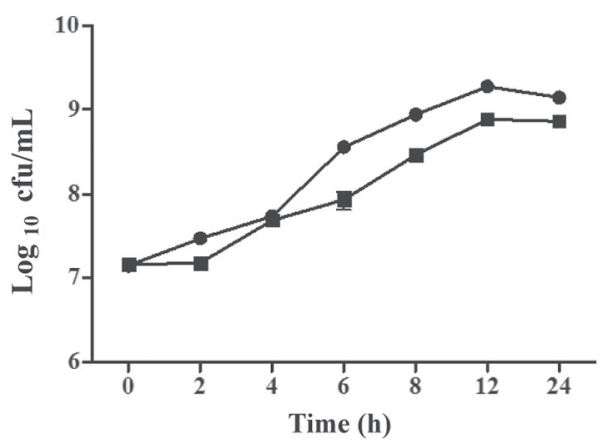

B) $\mathbf{J} 23$

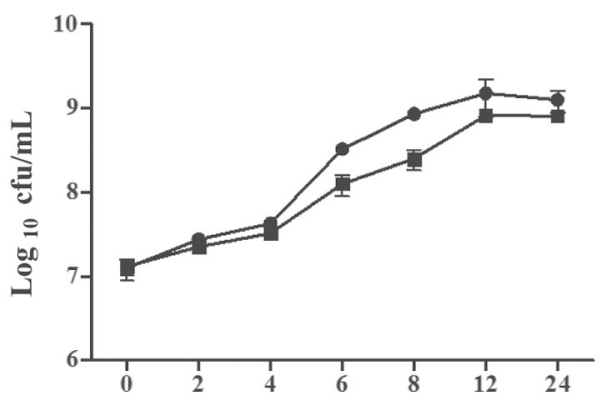

D)

J26

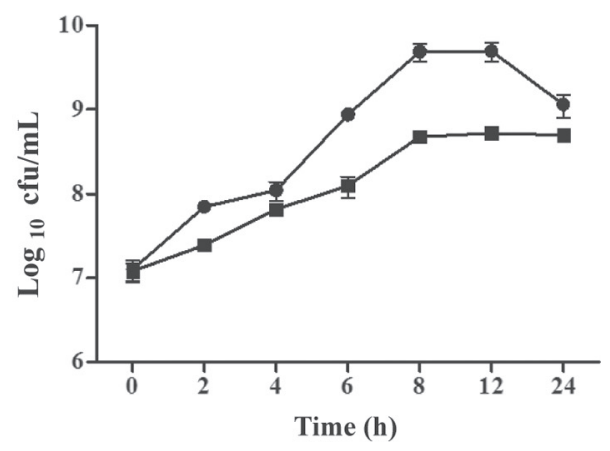

Figure 1. Survival of Lactobacillus strains ( Lb. fermentum J20, Lb. fermentum J23, Lb. plantarum J25, and Lb. pentosus J26) in simulated intestinal juice versus in de Man, Rogosa, and Sharpe (MRS) broth. Error bars represent SD. 

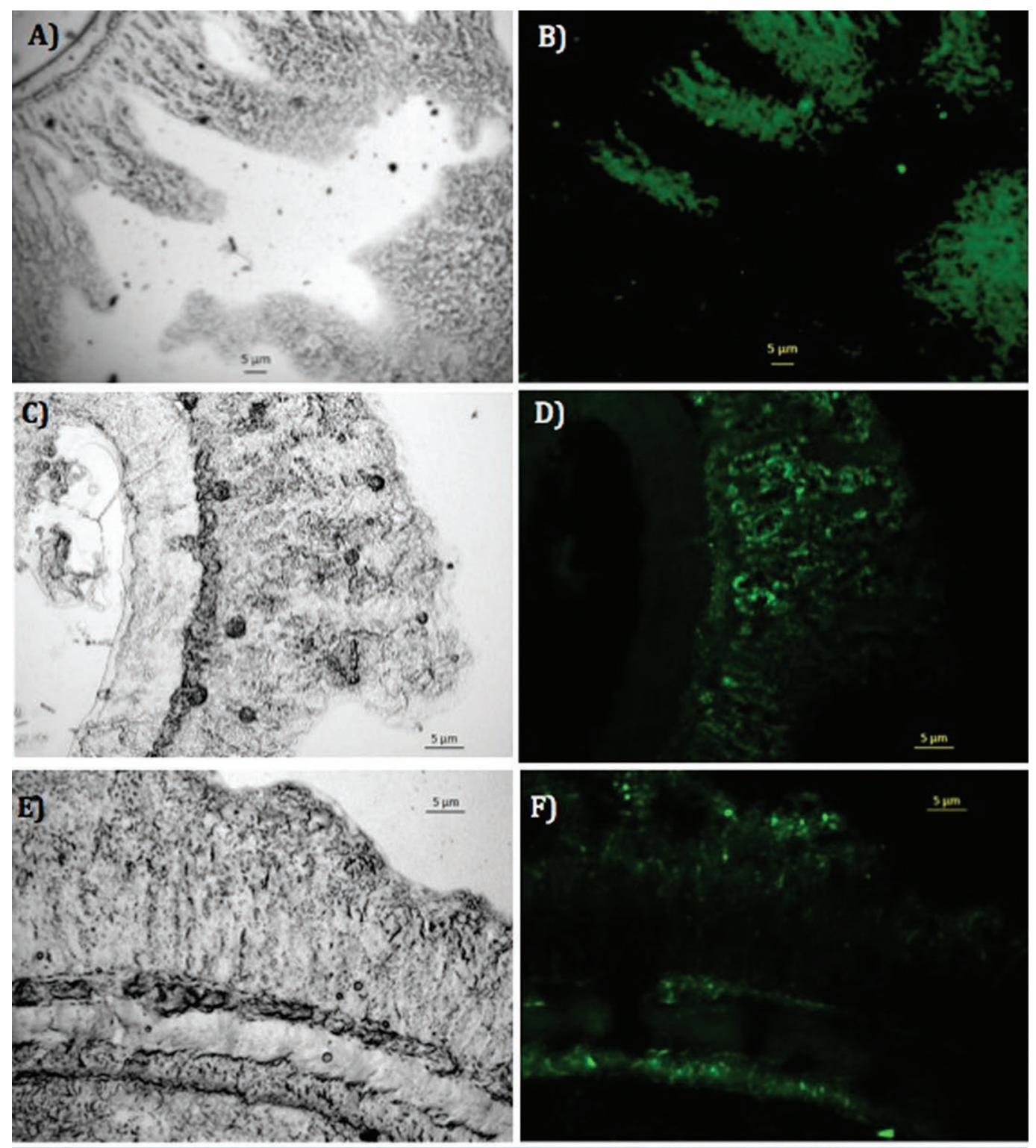

G)

Figure 2. Photographs of bacteria labeled with carboxyfluorescein diacetate succinimidyl ester (CFDA-SE) adhered to the intestinal tissue of rats. Duodenal intestinal tissue without $(\mathrm{A})$ and with $(\mathrm{B})$ fluorescence $(50 \times$ total magnification); jejunum intestinal tissue without (C) and with (D) fluorescence $(100 \times$ total magnification); ileum intestinal tissue without (E) and with (F) fluorescence (100× total magnification); fluorescence of labeled Lactobacillus (G; 1,000× total magnification). Color version available online. 
cantly $(P>0.05)$ different from that produced by $L b$. reuteri ATCC 55739, which is known to be a high CLA producer (Roman-Nunez et al., 2007). Other authors have reported that $L b$. plantarum 2 and $L b$. acidophilus $\mathrm{Ki}$ produced 17.54 and $0.89 \mu \mathrm{g} / \mathrm{mL}$, respectively, of CLA in milk after $48 \mathrm{~h}$ (Rodríguez-Alcalá et al., 2011), whereas Lb. acidophilus $\mathrm{O} 16$ and $L b$. casei E10 produced $54.31 \pm 4.13$ and $71.36 \pm 2.75 \mu \mathrm{g} / \mathrm{mL}$ after $24 \mathrm{~h}$ of fermentation (Alonso et al., 2003). Our results indicate that the ability of LAB to synthesize CLA in LA-RNDM was species and strain dependent. The variability in the amount of CLA produced by Lactobacillus strains can depend on both the linoleate isomerase activity, responsible for the conversion of LA to CLA in different isomeric forms, and by the strain's capacity to synthesize the enzyme (Farmani et al., 2010). Furthermore, the amount of CLA produced may be influenced by fermentation time and the concentration of LA added to the culture medium (Hernández-Mendoza et al., 2009). On the other hand, it is interesting to note that none of the strains assessed in this work were able to produce CLA in LA-MRS broth. In a related work, the production of CLA by 8 dairy bacteria tolerant to LA was 2- or 3-fold higher in milk than in MRS broth, and all tested strains were able to produce CLA with high LA levels $(1,000 \mathrm{mg} / \mathrm{mL}$ ) in milk (Van Nieuwenhove et al., 2007a). It has been reported that some milk compounds, such as proteins, can neutralize the toxic effects of FFA against bacteria, which may explain higher CLA production due to increased bacterial growth (Andrade et al., 2012).

The capacity of 4 Lactobacillus strains to adhere to intestinal epithelial cell of rats was also evaluated in this study. This property is very important because bacterial adhesion to epithelial cells supports the ability of microorganisms to colonize the specific tract of the host and to deliver health effects over an extended period (Kaushik et al., 2009). Adhesion determines the potential of these bacteria for production of CLA at the intestinal level. The stress to gastric juice is the first barrier that the bacteria must endure before arriving in the intestine, and these conditions can modify the intracellular $\mathrm{pH}$ of bacteria and cause death (Kajfasz and Quivey, 2011). The CLA-producing strains were able to survive under simulated gastric conditions. Other studies have reported similar results to those obtained in this study; for example, 4 strains of $L b$. fermentum (IMAU60129, IMAU60092, IMAU6008, and F6) decreased by 1 logarithmic cycle after being subjected to simulated gastric juice for $3 \mathrm{~h}$, whereas $7 \mathrm{Lb}$. fermentum strains decreased an average of 2 logarithmic cycles (Bao et al., 2010). On the other hand, Lb. casei DSPV 318T was highly resistant to simulated gastric juice (Frizzo et al., 2006). Other studies reported less resistance than that found in this study. For example, Lb. plantarum ssp. plantarum WCFS1 decreased 5 logarithmic cycles, whereas $L b$. plantarum ssp. plantarum DPC6429 decreased 8 logarithmic cycles upon exposure to simulated gastric juice (Guidone et al., 2014).

Additionally, the 4 Lactobacillus strains that produced CLA were able to survive under simulated intestinal conditions. Similar results were reported with 13 strains of Propionibacterium, of which 11 strains remained viable and without significant changes in cell concentration after being subjected to stress in simulated intestinal juice $(P>0.05)$, whereas the other 2 strains, Propionibacterium freudenreichii CSCC2207 and Propionibacterium acidopropionici 341, showed a decrease in their cell counts $(P<0.05)$ with exposure to simulated intestinal juice ( $\mathrm{pH} 8$ ) for $4 \mathrm{~h}$ (Huang and Adams, 2004). In other studies, L. acidophilus M92 showed high susceptibility: viable counts decreased 3 logarithmic cycles after being exposed to simulated intestinal juice for $4 \mathrm{~h}$ (Kos et al., 2000). These results might be due to the low bile salt tolerance of the lactobacilli assessed; the susceptibility of LAB to antimicrobial action of bile salt could be related to its low capacity to hydrolyze bile salts by the action of the bile salt hydrolase enzyme (Moser and Savage, 2001; Begley et al., 2005; Taranto et al., 2006). The results in the current study indicated that the ability to tolerate gastric or intestinal conditions is strain dependent.

The 4 Lactobacillus strains maintained their ability to produce CLA in simulated gastrointestinal conditions, although the production of CLA in milk was significantly $(P<0.05)$ greater than that in simulated gastrointestinal conditions. Strains J20, J23, and J25 produced $91.49,87.23$, and $36.03 \%$ more CLA in milk than in simulated gastrointestinal conditions, respectively. On the other hand, J26 produced a greater amount of CLA in simulated gastrointestinal conditions than in milk $(63.63 \%)$, which could be due to the conformational and structural changes of bacterial cell surface originated by the gastrointestinal simulated environment. In this respect, Roman-Nunez et al. (2007) studied the effect of bile acid (sodium glycolate) on the increase of CLA content. In that study, it was suggested that bile salt could alter the permeability of bacterial cells, allowing ingress of LA and access to linoleate isomerase, which is a soluble enzyme and an intracellular membrane-bound protein. Consequently, it is possible that a higher amount of CLA was produced.

In this study, we showed the intestinal adhesion capacities of the 4 CLA-producing Lactobacillus strains in the duodenum, jejunum, and ileum; the control group, administered an unlabeled culture of J20, showed no fluorescence, indicating a lack of adhesion capacity (data not shown). Considering that the CFDA-SE 
fluorophore does not adversely affect bacterial cell viability or adhesion (Fuller et al., 2000), is well retained in the cell (even during cell division), and is nontransferable to adjacent cells, including mammalian cells (Parish, 1999; Wang et al., 2005), the fluorescent staining method used in this work allowed the detection of Lactobacillus strains attached to epithelial tissue at different sections of the small intestine after its inoculation in vivo. Previous works have demonstrated the feasibility of CFDA-SE staining for in vivo testing of adhesion properties of lactic acid bacteria (Lee et al., 2004; Bouzaine et al., 2005; Duangjitcharoen et al., 2009). However, additional work is required to support the ability of the Lactobacillus strains assessed in this work to colonize and produce CLA at the intestinal level.

\section{CONCLUSIONS}

The results of this study indicated that $L b$. fermentum J20, Lb. fermentum J23, Lb. plantarum J25, and $L b$. pentosus J26 were capable of producing CLA in reconstituted NDM. These strains also showed the capacity to survive and produce CLA under simulated gastrointestinal conditions and to adhere to rat intestinal mucosa, suggesting that these strains could produce CLA in the intestine. Further studies are under way to test the health benefits that may be conferred by administration of these Lactobacillus strains in fermented milk.

\section{ACKNOWLEDGMENT}

This study was supported by the Mexican National Council of Science and Technology (CONACyT). The authors thank CONACyT for graduate scholarships to J. Sosa-Castañeda.

\section{REFERENCES}

Abd El-Salam, M. H., K. El-Shafei, O. M. Sharaf, B. A. Effat, F. M. Asem, and M. El-Aasar. 2010. Screening of some potentially probiotic lactic acid bacteria for their ability to synthesis conjugated linoleic acid. Int. J. Dairy Technol. 63:62-69.

Alonso, L., E. P. Cuesta, and S. E. Gilliland. 2003. Production of free conjugated linoleic acid by Lactobacillus acidophilus and Lactobacillus casei of human intestinal origin. J. Dairy Sci. 86:1941-1946.

Andrade, J. C., K. Ascencao, P. Gullon, S. M. S. Henriques, J. M. S. Pinto, T. A. P. Rocha-Santos, A. C. Freitas, and A. M. Gomes. 2012. Production of conjugated linoleic acid by food-grade bacteria: A review. Int. J. Dairy Technol. 65:467-481.

Bao, Y., Y. Zhang, Y. Zhang, Y. Liu, S. Wang, X. Dong, Y. Wang, and H. Zhang. 2010. Screening of potential probiotic properties of Lactobacillus fermentum isolated from traditional dairy products. Food Contr. 21:695-701.

Begley, M., C. G. M. Gahan, and C. Hill. 2005. The interaction between bacteria and bile. FEMS Microbiol. Rev. 29:625-651.
Benchaar, C., G. A. Romero-Perez, P. Y. Chouinard, F. Hassanat, M. Eugene, H. V. Petit, and C. Cortes. 2012. Supplementation of increasing amounts of linseed oil to dairy cows fed total mixed rations: Effects on digestion, ruminal fermentation characteristics, protozoal populations, and milk fatty acid composition. J. Dairy Sci. 95:4578-4590.

Bhattacharya, A., J. Banu, M. Rahman, J. Causey, and G. Fernandes. 2006. Biological effects of conjugated linoleic acids in health and disease. J. Nutr. Biochem. 17:789-810.

Bouzaine, T., R. D. Dauphin, Ph. Thonart, M. C. Urdaci, and M. Hamdi. 2005. Adherence and colonization properties of Lactobacillus rhamnosus TB1, a broiler chicken isolate. Lett. Appl. Microbiol. 40:391-396.

Chin, S. F., W. Liu, J. M. Storkson, Y. L. Ha, and M. W. Pariza. 1992 Dietary sources of conjugated dienoic isomers of linoleic acid, a newly recognized class of anticarcinogens. J. Food Compos. Anal. 5:185-197.

Chouinard, P. Y., L. Corneau, W. R. Butler, Y. Chilliard, J. K. Drackley, and D. E. Bauman. 2001. Effect of dietary lipid source on conjugated linoleic acid concentrations in milk fat. J. Dairy Sci. 84:680-690.

Correia, M., V. Michel, A. A. Matos, P. Carvalho, M. J. Oliveira, R. M. Ferreira, M.-A. Dillies, M. Huerre, R. Seruca, C. Figueiredo, J. C. Machado, and E. Touati. 2012. Docosahexaenoic acid inhibits Helicobacter pylori growth in vitro and mice gastric mucosa colonization. PLoS ONE 7:e35072 http://dx.doi.org/10.1371/journal pone.0035072

do Espirito Santo, A. P., N. S. Cartolano, T. F. Silva, F. A. Soares, L. A. Gioielli, P. Perego, A. Converti, and M. N. Oliveira. 2012 Fibers from fruit by-products enhance probiotic viability and fatty acid profile and increase CLA content in yoghurts. Int. J. Food Microbiol. 154:135-144.

Domagała, J., M. Sady, D. Najgebauer-Lejko, M. Czernicka, and I. Wieteska. 2009. The content of conjugated linoleic acid (CLA) in cream fermented using different starter cultures. Biotech. Anim. Husbandry 25:745-751.

Duangjitcharoen, Y., D. Kantachote, M. Ongsakul, N. Poosaran, and C. Chaiyasut. 2009. Potential use of probiotic Lactobacillus plantarum SS2 isolated from a fermented plant beverage: Safety assessment and persistence in the murine gastrointestinal tract. World J. Microbiol. Biotechnol. 25:315-321.

Farmani, J., M. Safari, F. Roohvand, S. H. Razavi, M. R. Aghasadeghi, and H. Noorbazargan. 2010. Conjugated linoleic acid-producing enzymes: A bioinformatics study. Eur. J. Lipid Sci. Technol. 112:1088-1100.

Fernández de Palencia, P., P. López, A. Corbí, C. Peláez, and T. Requena. 2008. Probiotic strains: survival under simulated gastrointestinal conditions, in vitro adhesion to Caco-2 cells and effect on cytokine secretion. Eur. Food Res. Technol. 227:1475-1484.

Florence, A., R. Silva, A. Santo, L. Gioielli, A. Tamime, and M. Oliveira. 2009. Increased CLA content in organic milk fermented by $B i-$ fidobacteria or yoghurt cultures. Dairy Sci. Technol. 89:541-553.

Flowers, G., S. A. Ibrahim, and A. A. AbuGhazaleh. 2008. Milk fatty acid composition of grazing dairy cows when supplemented with linseed oil. J. Dairy Sci. 91:722-730.

Folch, J., M. Lees, and G. H. Sloane Stanley. 1957. A simple method for the isolation and purification of total lipids from animal tissues. J. Biol. Chem. 226:497-509.

Fritsche, J., and H. Steinhart. 1998. Amounts of conjugated linoleic acid (CLA) in German foods and evaluation of daily intake. Z Lebensm. Unters. Forsch. 206:77-82.

Frizzo, L. S., L. P. Soto, E. Bertozzi, G. Sequeira, L. E. Marti, and M. R. Rosmini. 2006. In vitro evaluation of the microbial probiotic capacities focused to design of multispecies probiotic inocula to be used in breeding of calves. Rev. Cienc. Vet. 5:69-81.

Fuller, M. E., S. H. Streger, R. K. Rothmel, B. J. Mailloux, J. A. Hall, T. C. Onstott, J. C. Fredickson, D. L. Balkwill, and M. F. DeFlaun. 2000. Development of a vital fluorescent staining method for monitoring bacterial transport in subsurface environments. Appl. Environ. Microbiol. 66:4486-4496. 
Gagliostro, G. A. 2005. Nutritional control of conjugated linoleic acid (CLA) content in milk and in natural food. Rev. Arg. Prod. Anim. 24:137-163.

Gorissen, L., F. Leroy, L. De Vuyst, S. De Smet, and K. Raes. 2015. Bacterial production of conjugated linoleic and linolenic acid in foods: A technological challenge. Crit. Rev. Food Sci. Nutr. $55: 1561-1574$

Gorissen, L., S. Weckx, B. Vlaeminck, K. Raes, L. De Vuyst, S. De Smet, and F. Leroy. 2011. Linoleate isomerase activity occurs in lactic acid bacteria strains and is affected by $\mathrm{pH}$ and temperature. J. Appl. Microbiol. 111:593-606.

Guidone, A., T. Zotta, R. P. Ross, C. Stanton, M. C. Rea, E. Parente, and A. Ricciardi. 2014. Functional properties of Lactobacillus plantarum strains: A multivariate screening study. LWT- . Food Sci. Technol. (Campinas.) 56:69-76.

Herman-Lara, E., V. M. Santos-Blanco, M. A. Vivar-Vera, H. S. García, L. A. Ochoa-Martínez, and C. E. Martínez-Sánchez. 2012. Conjugated linoleic acid content in selected Mexican beef and dairy products. CyTA-J. Food 10:71-77.

Hernández-Mendoza, A., A. Lopez-Hernandez, C. G. Hill, and H. S. Garcia. 2009. Bioconversion of linoleic acid to conjugated linoleic acid by Lactobacillus reuteri under different growth conditions. J. Chem. Technol. Biotechnol. 84:180-185.

Huang, Y., and M. C. Adams. 2004. In vitro assessment of the upper gastrointestinal tolerance of potential probiotic dairy Propionibacteria. Int. J. Food Microbiol. 91:253-260.

Ip, C., D. J. Lisk, and J. A. Scimeca. 1994. Potential of food modification in cancer prevention. Cancer Res. 54:1957s-1959s.

Kabak, B., and F. Ozbey. 2012. Aflatoxin M1 in UHT milk consumed in Turkey and first assessment of its bioaccessibility using an in vitro digestion model. Food Contr. 28:338-344.

Kajfasz, J. K., and R. J. Quivey. 2011. Responses of lactic acid bacteria to acid stress. Pages 23-53 in Stress Responses of Lactic Acid Bacteria. E. Tsakalidou, and K. Papadimitriou, ed. Springer, New York, NY.

Kaushik, J. K., A. Kumar, R. K. Duary, A. K. Mohanty, S. Grover, and V. K. Batish. 2009. Functional and probiotic attributes of an indigenous isolate of Lactobacillus plantarum. PLOS ONE 4:e8099. http://dx.doi.org/10.1371/journal.pone.0008099.

Kim, Y. J., and R. H. Liu. 2002. Increase of conjugated linoleic acid content in milk by fermentation with lactic acid bacteria. J. Food Sci. 67:1731-1737.

Kos, B., J. Suskovic, J. Goreta, and S. Matosic. 2000. Effect of protectors on the viability of Lactobacillus acidophilus M92 in simulated gastrointestinal conditions. Food Technol. Biotechnol. 38:121127.

Lee, H. Y., J. H. Park, S. H. Seok, M. W. Baek, D. J. Kim, K. E. Lee, K. S. Paek, and Y. Lee. 2006. Human originated bacteria, Lactobacillus rhamnosus PL60, produce conjugated linoleic acid and show anti-obesity effects in diet-induced obese mice. Biochim. Biophys. Acta 1761:736-744.

Lee, K., and Y. Lee. 2009. Production of $c 9, t 11$ - and $t 10, c 12$-conjugated linoleic acids in humans by Lactobacillus rhamnosus PL60. J. Microbiol. Biotechnol. 19:1617-1619.

Lee, K., K. Paek, H. Y. Lee, J. H. Park, and Y. Lee. 2007. Antiobesity effect of trans-10,cis-12-conjugated linoleic acid-producing Lactobacillus plantarum PL62 on diet-induced obese mice. J. Appl. Microbiol. 103:1140-1146.

Lee, Y. K., P. S. Ho, C. S. Low, H. Arvilommi, and S. Salminen. 2004. Permanent colonization by Lactobacillus casei is hindered by the low rate of cell division in mouse gut. Appl. Environ. Microbiol. 70:670-674.

Lima Alves, L., N. Santos Richards, L. Mariutti, G. Nogueira, and N. Bragagnolo. 2011. Inulin and probiotic concentration effects on fatty and linoleic conjugated acids in cream cheeses. Eur. Food Res. Technol. 233:667-675.

Lin, H., T. D. Boylston, M. J. Chang, L. O. Luedecke, and T. D. Shultz. 1995. Survery of the conjugated linoleic acid contents of dairy products. J. Dairy Sci. 78:2358-2365.
Liu, P., S. R. Shen, H. Ruan, Q. Zhou, L. L. Ma, and G. Q. He. 2011. Production of conjugated linoleic acids by Lactobacillus plantarum strains isolated from naturally fermented Chinese pickles. J. Zhejiang Univ. Sci. B 12:923-930.

Moser, S. A., and D. C. Savage. 2001. Bile salt hydrolase activity and resistance to toxicity of conjugated bile salts are unrelated properties in Lactobacilli. Appl. Environ. Microbiol. 67:3476-3480.

Nunes, J. C., and A. G. Torres. 2010. Fatty acid and CLA composition of Brazilian dairy products, and contribution to daily intake of CLA. J. Food Compos. Anal. 23:782-789.

O'Shea, M., J. Bassaganya-Riera, and I. C. Mohede. 2004. Immunomodulatory properties of conjugated linoleic acid. Am. J. Clin. Nutr. 79:1199S-1206S.

Pandit, A., S. Anand, K. Kalscheur, and A. Hassan. 2012. Production of conjugated linoleic acid by lactic acid bacteria in milk without any additional substrate. Int. J. Dairy Technol. 65:603-608.

Parish, C. R. 1999. Fluorescent dyes for lymphocyte migration and proliferation studies. Immunol. Cell Biol. 77:499-508.

Park, Y. 2009. Conjugated linoleic acid (CLA): Good or bad trans fat? J. Food Compos. Anal. 22:4-12.

Prandini, A., S. Sigolo, G. Tansini, N. Brogna, and G. Piva. 2007. Different level of conjugated linoleic acid (CLA) in dairy products from Italy. J. Food Compos. Anal. 20:472-479.

Puniya, A., C. Reddy, S. Kumar, and K. Singh. 2009. Influence of sunflower oil on conjugated linoleic acid production by Lactobacillus acidophilus and Lactobacillus casei. Ann. Microbiol. 59:505-507.

Rett, B. S., and J. Whelan. 2011. Increasing dietary linoleic acid does not increase tissue arachidonic acid content in adults consuming Western-type diets: A systematic review. Nutr. Metab. (Lond.) 8:36.

Rodríguez-Alcala, L. M., T. Braga, F. Xavier Malcata, A. Gomes, and J. Fontecha. 2011. Quantitative and qualitative determination of CLA produced by Bifidobacterium and lactic acid bacteria by combining spectrophotometric and Ag+-HPLC techniques. Food Chem. 125:1373-1378.

Roman-Nunez, M., E. P. Cuesta-Alonso, and S. E. Gilliland. 2007. Influence of sodium glycocholate on production of conjugated linoleic acid by cells of Lactobacillus reuteri ATCC 55739 . J. Food Sci. 72:M140-143.

Taranto, M. P., G. Perez-Martinez, and G. Font de Valdez. 2006. Effect of bile acid on the cell membrane functionality of lactic acid bacteria for oral administration. Res. Microbiol. 157:720-725.

Van Nieuwenhove, C. P., R. Oliszewski, S. N. Gonzalez, and A. B. Perez Chaia. 2007a. Conjugated linoleic acid conversion by dairy bacteria cultured in MRS broth and buffalo milk. Lett. Appl. Microbiol. 44:467-474.

Van Nieuwenhove, C. P., R. Oliszewski, S. N. González, and A. B. Pérez Chaia. 2007b. Influence of bacteria used as adjunct culture and sunflower oil addition on conjugated linoleic acid content in buffalo cheese. Food Res. Int. 40:559-564.

Wall, R., R. P. Ross, F. Shanahan, L. O'Mahony, C. O'Mahony, M. Coakley, O. Hart, P. Lawlor, E. M. Quigley, B. Kiely, G. F. Fitzgerald, and C. Stanton. 2009. Metabolic activity of the enteric microbiota influences the fatty acid composition of murine and porcine liver and adipose tissues. Am. J. Clin. Nutr. 89:1393-1401.

Wang, X. Q., X. M. Duan, L. H. Liu, Y. Q. Fang, and Y. Tan. 2005. Carboxyfluorescein diacetate succinimidyl ester fluorescent dye for cell labeling. Acta Biochim. Biophys. Sin. (Shanghai) 37:379-385.

Whigham, L. D., A. C. Watras, and D. A. Schoeller. 2007. Efficacy of conjugated linoleic acid for reducing fat mass: A meta-analysis in humans. Am. J. Clin. Nutr. 85:1203-1211.

Xu, S., T. Boylston, and B. Glatz. 2004. Effect of lipid source on probiotic bacteria and conjugated linoleic acid formation in milk model systems. J. Am. Oil Chem. Soc. 81:589-595. 